\title{
Sustainability of sharia rural bank in Central Java
}

\author{
Rosida Dwi Ayuningtyas", Rosita Wati, Fitroh Safa'ah \\ Program Studi Ekonomi Islam, Fakultas Ekonomi, Universitas Wahid Hasyim, Semarang, Indonesia \\ *Corresponding Author: rosida@unwahas.ac.id
}

\section{Keywords: \\ Financial Sustanability Rasio (FSR), Bank Pembiayaan Rakyat Syariah, NPF, ROA, FDR, OER, CAR. \\ DOI: \\ 10.20885/JEKI.vol4.iss2.art1}

\begin{abstract}
Abstact
This study analyzes the sustainability of the Islamic people's financing bank (BPRS) in Central Java in the period 2013 to 2017. The variables used in this study are financial sustainability ratio (FSR), non-performing financing, return on assets, financing debt ratio, operating expenses and capaital adequacy ratio. The sample selected in this study is 10 BPRS where the sample has published financial reports in Indonesian banks in 2013 to 2017. The analysis method used is panel data regression with the fixed effect method. In the test results that CAR partially has a positive effect on the financial sustainability ratio, while OER partially negatively affects the financial sustainability ratio. Based on the test results, BRPS Mount Slamet has the highest FSR value of $3.32 \%$, while the lowest FSR is BPRS Saka Dana Mulia of $2.36 \%$.
\end{abstract}

\section{Background}

Indonesia is a country with a good potential in economics particularly in industrial sector. Abdul Kadir Damanik as a staff of Ministry of KUKM (2026) said that the total of SME players could reach 57.9 million at 2014, and around $98 \%$ of that is micro enterprises. Small and Medium Enterprises (SMEs) are part of business actors which have a large contribution in creating jobs in Indonesia. Therefore, the existence of SMEs is needed by the community, especially those with low economic independency and limited skills to generate income or to develop potential/skills they have (Maryati, 2014). In developing larger SMEs, sufficient access to capital is needed so that the skills possessed by SME entrepreneurs in producing goods can help improving competitiveness in running their businesses. The capital owned by informal-sector entrepreneurs is relatively small so that it will be difficult to increase their productivity due to the lack of access to external financing (Parinduri, 2016).

Sharia Rural Bank (BPRS) is a sharia-based financial institution that has a funding focus on small micro sector, where the BPRS will interact directly with SME business players who need funding. The existence of BPRS in Indonesia has an important role for the local and independent business, because BPRS is established to create easy access for small business actors to develop production and economic activities. The development of BPRS in Central Java as of March 2018 shows a significant increase, indicated by the total assets of BPRS in Central Java reached IDR 1,327,241 trillion. Not only the total assets increased, the amount of financing to the public, Third Party Funds, reached up to IDR 963,097 billion from IDR 921,640 billion. While the liquidity ratio indicated by Financing to Deposit Ratio (FDR) reached $111.53 \%$ and the credit ratio indicated by Non Performing Financing (NPF) reached 10.98\% (Financial Services Authority, 2018).

The performance of BPRS in Central Java shows good performance, indicated by the ability of BPRS to contribute well by providing business capital for small and medium enterprises. This achievement is also supported by the ability of BPRS to reach out the people from middle to lower economic groups which have not been reached by commercial banks, both Islamic and conventional. In order to obtain high profits, BPRS must 
conduct business or activities that support the growth rate of BPRS, meaning that BPRS or bank in general is categorized as effective or efficient if the bank is able to maintain its performance well and reduce the level of risk that will occur in the future (Almilia, et al, 2009).

Financial Sustanability is the ability of an institution to be able to compare all costs with the total income received from the activities executed. A good standard for financial sustainability ratio is (FSR> 100\%). To achieve a high FSR, the total financial income must be higher than the financial burden, which means that if FSR shows a high number then a bank is highly expected to be able to continue its operations. According to Soeksmono in Almilia (2009), financial sustainability is a measurement tool to assess the efficiency of an institution. This ratio is used to determine the growth rate of each period so that the financial performance of financial institutions can be known to decide whether they can continue their operations or not.

Almilia, et al. (2009) shows that in the pre-crisis period (1995-1996), LDR had a significant negative effect on Financial Sustainability Ratio (FSR), which means that the greater the LDR of banks, the lower the liquidity capability of the bank (the amount of funds needed to finance credit becomes greater). This further exacerbates the bank's ability to go concern, while for the crisis period (1997-1999), the ROA variable had a significant positive effect on FSR; while NPL had a significant negative effect on FSR . Meanwhile, according to Sundari, et al. (2012), the factors that influence financial sustainability of microfinance institutions in East Java are CAR, ROA, ROE, LDR, NPL, and HRD, while factors that have no significant effect are competition and income per capita.

Rianasari, et al. (2016) explained that the factors that influence financial sustainability ratio (FSR) at Rural Banks in Central Java (2010-2014) include ROA, SIZE, LDR with a positive influence, which means that if ROA, SIZE and LDR increase, FSR will also increase; while NPL, Cash Ratio, Deposit Mobilization and age negatively affect FSR, which means that if NPL, Cash Ratio, Deposit Mobilization and age increase decrease, FSR will also decrease. Whereas according to Marwati and Yulianti (2015), it shows that ROA has a positive effect on sustainability report, size and EPS has a negative effect on sustainability report, while the current ratio does not affect sustainability report. According to the results of Notoatmojo and Anita's research (2016), the factors that positively influence the sustainability ratio of Sharia Commercial Banks in 2010-2014 are CAR, ROA, FDR, while the variables of NPL, ROE and OER negatively affect the sustainability ratio. According to the results of Santoso et al. (2017), the factors that affect the financial sustainability ratio are CAR and LDR while NPL does not affect financial sustainability ratio of private and public commercial banks listed on Indonesia Stock Exchange in 2011-2015. In creating a robust and strong Rural Sharia Bank (BPRS) in Central Java, it needs to be supported by significant asset growth. Thus, it can improve sharia product services to SMEs optimally, where it will have an impact on increasing public trust in BPRS through low Non Performing Financing (NPF), well-maintained Financing to Deposit (FDR), Return on Assets (ROA), Operating Expense Ratio (OER) and Capital Adequacy Ratio (CAR. Therefore, this study will discuss what factors will affect the sustainability of BPRS in Central Java from 2013 to 2017. In this study, the independent variables are NPF, FDR, ROA, OER and CAR, while the dependent variable is financial sustainability ratio (FSR). The theoretical framework in this research as follows:

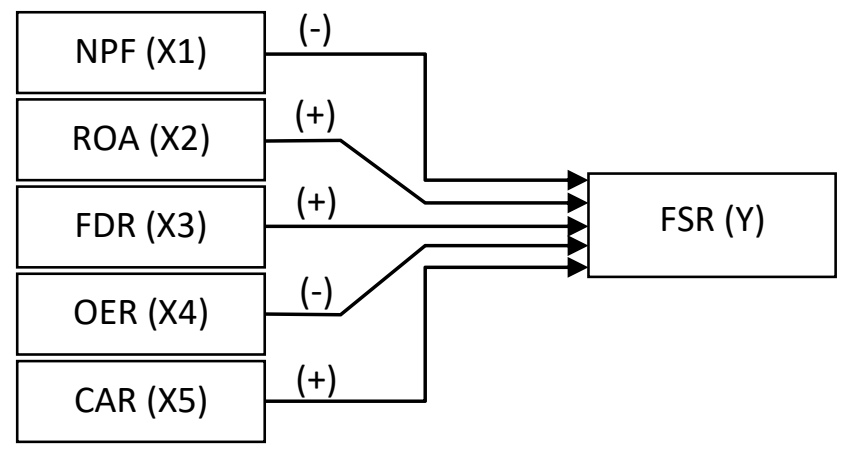

Picture 1. Theoretical Framework

\section{Research Method}

The population in this study is all BPRS in Central Java. Samples are chosen by purposive random sampling where the researcher randomly take a sample from the population of the BPRS whose semester financial reports were published at Bank Indonesia during 2013 to 2017. The research objects in this study are: 1) PT BPRS Artha Amanah Ummat, 2) PT BPRS Asad Alif, 3) PT BPRS Gala Mitra Abadi, 4) PT BPRS Artha Mas Abadi, 5) PT 
BPRS Saka Dana Mulia, 6) PT BPRS Bina Amanah Satria, 7) PT BPRS Suriyah, 8) PT BPRS Gunung Slamet, 9) PT BPRS Buana Mitra Perwira, 10) PT BPRS Meru Sankara.

The data used in this study is secondary data in the form of semester reports from 2013 to 2017. The data is obtained from BPRS annual financial report at www.bi.go.id, with a cross section consisting of 10 BPRS in Central Java with a range of studies from 2013 to 2017. The variables used in this study are Financial Sustanability Ratios, Return On Assets (ROA), Financing Debt Ratio (FDR), Non Performing Financing (NPF), Operating Expenses Ratio (OER), and Capital Adequacy Ratio (CAR). Data analysis is the process of simplifying data in a form that is easily interpreted. This study used econometric models for panel data. The equation for the linear regression is:

$\mathbf{Y}_{\mathrm{i}}=\boldsymbol{\beta}_{0}+\boldsymbol{\beta}_{1} \mathbf{X}_{1}+\boldsymbol{\beta}_{2} \mathbf{X}_{2}+\beta_{3} \mathbf{X}_{3}+\beta_{4} \mathbf{X}_{4}+\mathbf{e}_{i t}$

Note :

$\mathrm{Yi}=$ Financial Sustanability Rasio, $\beta_{0}=$ Constant, $\beta_{1}, \beta_{2}, \beta_{3}, \beta_{4}=$ Coefficient of Independent Variable, $\mathrm{X}_{1}=$ Non Performing Financing (NPF), $X_{2}=$ Financing Debt Ratio (FDR), $X_{3}=$ Return On Asset (ROA), $X_{4}=$ Operating Expense to Operating Revenue (OER), $\mathrm{X}_{5}=$ Capital Adequacy Ratio (CAR)

The collected data is assessed and tested based on a clearly-stated variable analysis and definite formulas. Data Panel Regression is a regression that uses a panel data which is a combination of cross-time and cross-individual data. The use of panel data in this study has various advantages compared to time series or cross section data.

$Y_{i}=\beta_{0}+\beta_{1} X_{i}+\mu_{i}: i=1,2, \ldots, N$

where $\mathrm{N}$ is the number of cross-section data. While equation model for time series is:

$Y_{t}=\beta_{0}+\beta_{1} X_{t}+\mu_{t} ; t=1,2, \ldots, T$

where $\mathrm{T}$ is the number of time series data.

Considering panel data panel is a combination of time series and cross section, the equation model can be formulated as follows:

$\mathbf{Y}_{\mathrm{it}}=\boldsymbol{\beta}_{\mathbf{0}}+\boldsymbol{\beta}_{\mathbf{1}} \mathbf{X}_{\mathrm{it}}+\boldsymbol{\mu}_{\mathrm{it}}$

$\mathrm{i}=1,2, \ldots, \mathrm{N} ; \mathrm{t}=1,2, \ldots, \mathrm{T}$

where :

$\mathrm{N}=$ Number of observation, $\mathrm{T}=$ number of times, $\mathrm{N} \times \mathrm{T}=$ number of panel data

The analysis method of panel data has three (3) approaches (Sriyana, 2014) which are:

1) Common Effect assumes that intercept and slope is consistent over the time and individuals, the difference between intercept and slope is assumed to be explained by error term. The formula for common effect model is:

$$
\mathbf{Y}_{i t}=\beta_{0}+\beta_{1} \mathbf{X}_{1 i t}+\beta_{2} \mathbf{X}_{2 i t}+\beta_{3} \mathbf{X}_{3 i t}+\beta_{4} \mathbf{X}_{4 i t}+\mathbf{e}_{i t}
$$

2) Fixed Effect assumes that consistent intercept and slope is hard to reach. To overcome that problem is by adding dummy variables to allow the difference of parametric value across the time and unit. The formula for fixed effect model is:

$$
Y_{i t}=\beta_{0}+\beta_{1} X_{1 i t}+\beta_{2} X_{2 i t}+\beta_{3} X_{3 i t}+\beta_{4} D_{1 i t}+\beta_{5} D_{2 i t}+\beta_{6} D_{3 i t}+\ldots+e_{i t}
$$

Where: $\mathrm{D}_{1}=\mathrm{A}$ value, $\mathrm{D}_{2}=\mathrm{B}$ value, $\mathrm{D}_{3}=\mathrm{C}$ value, $\mathrm{D}_{4}=\mathrm{D}$ value

3) Random effect assume that adding dummy variable will lower degree of freedom which then will reduce the efficiency of the estimated parameter. The formula for random effect model is:

$$
\mathbf{Y}_{\text {it }}=\beta_{0 i}+\beta_{1} X_{1 i t}+\beta_{2} X_{2 i t}+\beta_{3} X_{3 i t}+\beta_{4} X_{4 i t}+e_{i t}
$$

The selection of the model to be used in the research needs to be done because to know whether the model is suitable or good to use in the research or not. A good method for selecting models in data processing is as follows: 


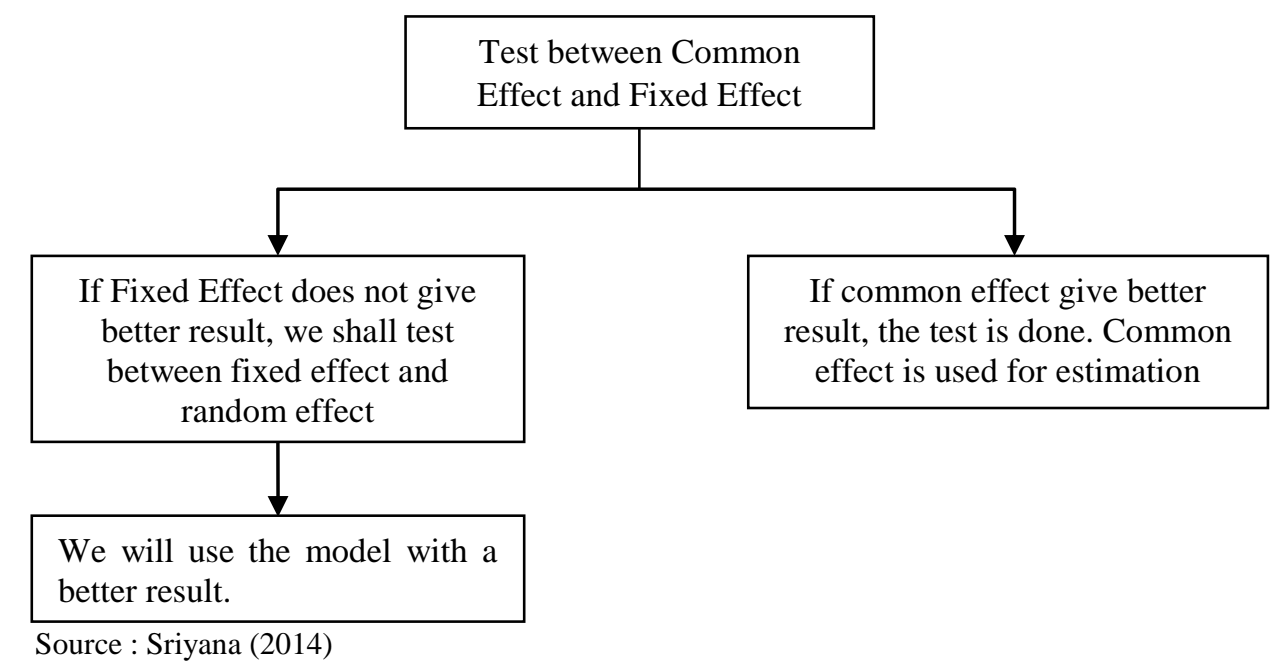

Picture 2: Prosedure to Determine Among Common Effect, Fixed Effect, Random Effect

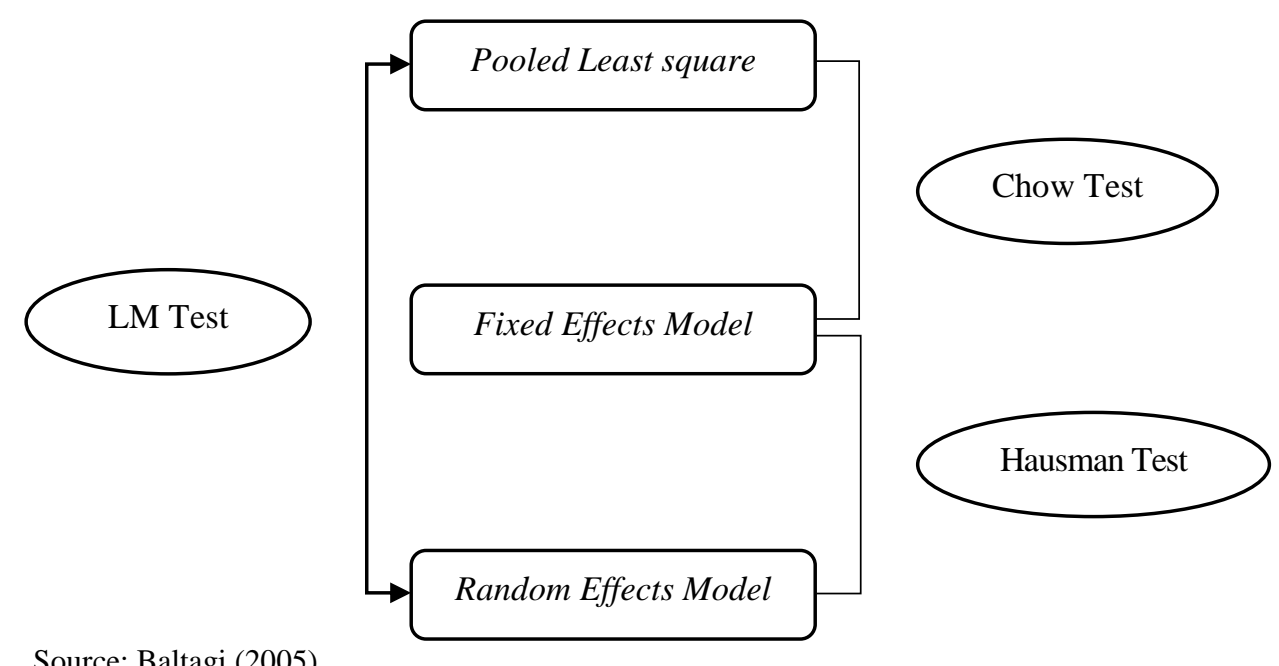

Source: Baltagi (2005)

Picture 3: Test for Choosing Among Common Effects, Fixed Effect and Random Effect

\section{Chow Test}

Chow test is a test used to choose between common effect and fixed effect estimation models, this test is the initial stage to choose which model is appropriate in the study, whether common effect or fixed effect model. The test is done by determining the hypothesis test in which if the P-value of chi Square $<0.05$ (sig value), then Ho is rejected, meaning that an appropriate model used is Fixed Effect. However, if P-value chi square $>0.05$ (sig value) then Ho is accepted, meaning that an appropriate model used is common effect (Widarjono, 2017).

\section{Hausman Test}

Hausman test is used to choose the model used between fixed effect and random effect estimation model, this test is carried out when the result of Chow test (the initial stage) indicates that fixed effect is the appropriate model, thus it needs to have the second testing stage, namely Hausman test with Hypothesis test: if P-value $<0.05$ then Ho is rejected, meaning that an appropriate model is fixed effect, while if $\mathrm{P}$-value $>0.05$ then Ho is accepted, meaning that an appropriate model is random effect.

T-test is conducted to find out whether the independent variable has a partial effect on the dependent variable or not. If the probability value t-statistic $>0.05$ then Ho is accepted, meaning that the independent variable does not affect the dependent variable. While if the probability value is $<0.05$ then Ho is rejected, 
meaning that the independent variable affects the dependent variable. F-test is used to determine whether the independent variables simultaneously affect the dependent variable. If the probability value f-statistic $>0.05$ then Ho is accepted, meaning that the independent variables simultaneously do not affect the dependent variable. While if the probability value f-statistic $<0.05$ then Ho is rejected, meaning that the independent variables simultaneously affect the dependent variable.

\section{Result and Discussion}

This research aims to analyze the sustainability of BPRS in Central Jawa during 2013 until 2017 quartally. Based on the thecnical estimation, regression model with panel data can be estimated using there estimation method which are Common Effects, Fixed Effect and Random Effect.

\section{Choosing between Common Effects and Fixed Effects}

Table 1. Redundant Fixed Effects Tests

\begin{tabular}{lrrr}
\hline Redundant Fixed Effects Tests & & & \\
\hline Pool: POOL & & & \\
Test cross-section fixed effects & Statistic & d.f. & Prob. \\
Effects Test & 10.661798 & $(9,157)$ & 0.0000 \\
Cross-section F & 82.038921 & 9 & 0.0000 \\
Cross-section Chi-square &
\end{tabular}

Source: Processed Result from E-Views (2018)

Based on the result on Table 1, it shows that P-value chi square is 0.000 which means that the probability is lower than $\alpha 5 \%$, where Ho is rejected and the appropriate model used in this study is fixed effects model. Thus, the next stage is to do Hausman test. It is used to choose between fixed effect and random effect.

\section{Choosing between Fixed Effect and Random Effect}

Table 2. Hausman Test

\begin{tabular}{lrrr}
\hline Correlated Random Effects - Hausman Test & & & \\
\hline Pool: POOL & & & \\
Test cross-section random effects & Chi-Sq. Statistic & Chi-Sq. d.f. & Prob. \\
Test Summary & 46.040190 & 5 & 0.0000 \\
Cross-section random & & &
\end{tabular}

Table 2 shows that $\mathrm{P}$-value chi square is 0.000 which means that probability is lower than $\alpha 5 \%$, where Ho is rejected and the appropriate model used in this study is fixed effect model.

\section{Identification of Estimation Result of Panel Data Linear Regression}

Table 3. The Result of Panel Data Panel Regression using Fixed Effect model

\begin{tabular}{|c|c|c|c|c|}
\hline Variable & Coefficient & Std. Error & t-Statistic & Prob. \\
\hline NPF? & 0.001423 & 0.004533 & 0.313926 & 0.7540 \\
\hline FDR? & -0.000380 & 0.001099 & -0.345897 & 0.7299 \\
\hline ROA? & 0.000503 & 0.001042 & 0.482902 & 0.6298 \\
\hline OER? & -1.403702 & 0.168873 & -8.312161 & 0.0000 \\
\hline CAR? & 0.003084 & 0.001207 & 2.553872 & 0.0116 \\
\hline $\mathrm{C}$ & $\begin{array}{c}2.651261 \\
\text { Effects Speci }\end{array}$ & $\begin{array}{l}0.144158 \\
\text { ification }\end{array}$ & 18.39134 & 0.0000 \\
\hline $\begin{array}{l}\text { Cross-section fixed (dummy variables) } \\
\text { R-squared }\end{array}$ & 0.778695 & $\begin{array}{l}\text { F-statistic } \\
\text { Prob(F-statistic) }\end{array}$ & & $\begin{array}{l}39.45919 \\
0.000000 \\
\end{array}$ \\
\hline
\end{tabular}

Source: Processed Result from E-Views (2018) 
Here is the equation model of fixed effect:

$\mathrm{FSR}_{\mathrm{t}}=\mathbf{2 . 6 5}+0.001 \mathrm{NPF}_{\mathrm{t}}-0.0003 \mathrm{FDR}_{\mathrm{t}}+0.0005 \mathrm{ROA}_{\mathrm{t}}-1.40 \mathrm{OER}_{\mathrm{t}}+0.003 \mathrm{CAR}$

Table 3 shows that OER has a negative effect on Financial Sustainability Ratio with probability of 0.000 less than $\alpha 5 \%$ which means that if OER experiences a decrease of $1 \%$ then FSR will increase by $2.65 \%$, because the smaller OER can interpreted that the company is efficient towards the use of corporate funds which will have an impact on the sustainability of company, in this case BPRS in Central Java.

Based on table 3, Capital Adequacy Ratio (CAR) also affects FSR with probability of 0.0116 less than $\alpha$ of $5 \%$, which means that the greater the CAR, the greater the FSR will be. The increase of CAR will have a positive impact on the sustainability of a company in this case, BPRS in Central Java. The results of F-test on Table 3 shows a significant influence with a probability value of 0.0000 less than $\alpha 5 \%$, which means that all independent variables (NPF, FDR, ROA, OER and CAR) simultaneously affect Financial Sustanability Ratio. The model performance is also pretty good, with $\mathrm{R}^{2}$ of $77.86 \%$.

Table 4. Constant for every BPRS in Central Java

\begin{tabular}{lc}
\hline \multicolumn{1}{c}{ Name of BPRS } & Intercept \\
\hline BPRS Artha Amanah Ummat & 0.252765 \\
BPRS Asad Alif & -0.149822 \\
BPRS Gala Mitra Abadi & -0.044281 \\
BPRS Artha Mas Abadi & -0.130955 \\
BPRS Saka Dana Mulia & -0.291789 \\
BPRS Bina Amanah Satria & -0.236835 \\
BPRS Suriyah & 0.090052 \\
BPRS Gunung Slamet & 0.671616 \\
BPRS Buana Mitra Perwira & -0.121736 \\
BPRS Meru Sankara. & -0.198028 \\
\hline
\end{tabular}

Source: Processed Result from E-Views (2018)

The estimated value of each BPRS will have an influence on FSR with the details as follow: 25.27 percent for SRB Artha Amanah Ummat, -14.98 percent for SRB Asad Alif, -4. 42 percent for BPRS Gala Mitra Abadi, -13.09 for BPRS Artha Mas Abadi, -.29.17 percent BPRS Saka Dana Mulia, -23.38 percent BPRS Bina Amanah Satria, 9 percent for BPRS Suriyah, 67.16 percent for BPRS Gunung Slamet, -12.17 percent for BPRS Buana Mitra Perwira, and -19.80 percent for SRB Meru Sankara. The equations of each company for Cross Effect model are as follows:

The equation for BPRS Artha Amanah Ummat

$\mathrm{FSR}_{\mathrm{t}}=(\mathbf{0 . 2 5}+\mathbf{2 . 6 5})+0.001 \mathrm{NPF}_{\mathrm{t}}-0.0003 \mathrm{FDR}_{\mathrm{t}}+0.0005 \mathrm{ROA}_{\mathrm{t}}-1.40 \mathrm{OER}_{\mathrm{t}}+0.003 \mathrm{CAR}$

$\mathrm{FSR}=\mathbf{2 . 9}+0.001 \mathrm{NPF}_{\mathrm{t}}-0.0003 \mathrm{FDR}_{\mathrm{t}}+0.0005 \mathrm{ROA}_{\mathrm{t}}-1.40 \mathrm{OER}_{\mathrm{t}}+0.003 \mathrm{CAR}$

Persamaan untuk BPRS Asad Alif

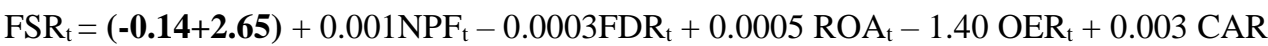

$\mathrm{FSR}=\mathbf{2 . 5 1}+0.001 \mathrm{NPF}_{\mathrm{t}}-0.0003 \mathrm{FDR}_{\mathrm{t}}+0.0005 \mathrm{ROA}_{\mathrm{t}}-1.40 \mathrm{OER}_{\mathrm{t}}+0.003 \mathrm{CAR}$

The equation for BPRS Gala Mitra Abadi

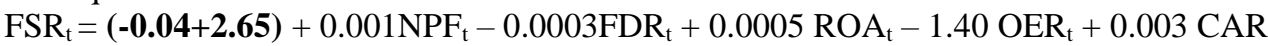

$\mathrm{FSR}=\mathbf{2 . 6 1}+0.001 \mathrm{NPF}_{\mathrm{t}}-0.0003 \mathrm{FDR}_{\mathrm{t}}+0.0005 \mathrm{ROA}_{\mathrm{t}}-1.40 \mathrm{OER}_{\mathrm{t}}+0.003 \mathrm{CAR}$

The equation for BPRS Artha Mas Abadi

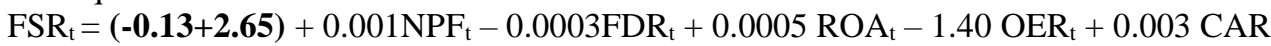

$\mathrm{FSR}=\mathbf{2 . 5 2}+0.001 \mathrm{NPF}_{\mathrm{t}}-0.0003 \mathrm{FDR}_{\mathrm{t}}+0.0005 \mathrm{ROA}_{\mathrm{t}}-1.40 \mathrm{OER}_{\mathrm{t}}+0.003 \mathrm{CAR}^{-}$

The equation for BPRS Saka Dana Mulia

$\mathrm{FSR}_{\mathrm{t}}=(\mathbf{- 0 . 2 9}+\mathbf{2 . 6 5})+0.001 \mathrm{NPF}_{\mathrm{t}}-0.0003 \mathrm{FDR}_{\mathrm{t}}+0.0005 \mathrm{ROA}_{\mathrm{t}}-1.40 \mathrm{OER}_{\mathrm{t}}+0.003 \mathrm{CAR}$

$\mathrm{FSR}=\mathbf{2 . 3 6}+0.001 \mathrm{NPF}_{\mathrm{t}}-0.0003 \mathrm{FDR}_{\mathrm{t}}+0.0005 \mathrm{ROA}_{\mathrm{t}}-1.40 \mathrm{OER}_{\mathrm{t}}+0.003 \mathrm{CAR}$ 
Persamaan untuk BPRS Bina Amanah Satria

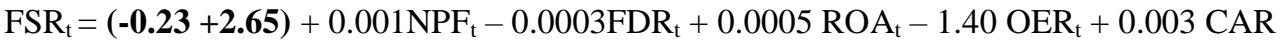

$\mathrm{FSR}=\mathbf{2 . 4 2}+0.001 \mathrm{NPF}_{\mathrm{t}}-0.0003 \mathrm{FDR}_{\mathrm{t}}+0.0005 \mathrm{ROA}_{\mathrm{t}}-1.40 \mathrm{OER}_{\mathrm{t}}+0.003 \mathrm{CAR}$

The equation for BPRS Suriyah

$\mathrm{FSR}_{\mathrm{t}}=(\mathbf{0 . 0 9}+\mathbf{2 . 6 5})+0.001 \mathrm{NPF}_{\mathrm{t}}-0.0003 \mathrm{FDR}_{\mathrm{t}}+0.0005 \mathrm{ROA}_{\mathrm{t}}-1.40 \mathrm{OER}_{\mathrm{t}}+0.003 \mathrm{CAR}$

$\mathrm{FSR}=\mathbf{2 . 7 4}+0.001 \mathrm{NPF}_{\mathrm{t}}-0.0003 \mathrm{FDR}_{\mathrm{t}}+0.0005 \mathrm{ROA}_{\mathrm{t}}-1.40 \mathrm{OER}_{\mathrm{t}}+0.003 \mathrm{CAR}$

The equation for BPRS Gunung Slamet

$\mathrm{FSR}_{\mathrm{t}}=(\mathbf{0 . 6 7}+\mathbf{2 . 6 5})+0.001 \mathrm{NPF}_{\mathrm{t}}-0.0003 \mathrm{FDR}_{\mathrm{t}}+0.0005 \mathrm{ROA}_{\mathrm{t}}-1.40 \mathrm{OER}_{\mathrm{t}}+0.003 \mathrm{CAR}$

$\mathrm{FSR}=\mathbf{3 . 3 2}+0.001 \mathrm{NPF}_{\mathrm{t}}-0.0003 \mathrm{FDR}_{\mathrm{t}}+0.0005 \mathrm{ROA}_{\mathrm{t}}-1.40 \mathrm{OER}_{\mathrm{t}}+0.003 \mathrm{CAR}$

The equation for BPRS Buana Mitra Perwira

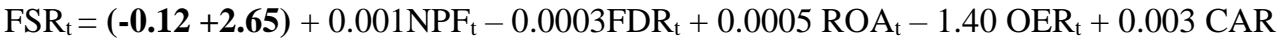

$\mathrm{FSR}=\mathbf{2 . 5 3}+0.001 \mathrm{NPF}_{\mathrm{t}}-0.0003 \mathrm{FDR}_{\mathrm{t}}+0.0005 \mathrm{ROA}_{\mathrm{t}}-1.40 \mathrm{OER}_{\mathrm{t}}+0.003 \mathrm{CAR}$

The equation for BPRS Meru Sankara

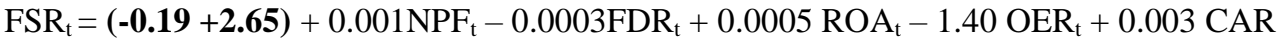

$\mathrm{FSR}=\mathbf{2 . 4 6}+0.001 \mathrm{NPF}_{\mathrm{t}}-0.0003 \mathrm{FDR}_{\mathrm{t}}+0.0005 \mathrm{ROA}_{\mathrm{t}}-1.40 \mathrm{OER}_{\mathrm{t}}+0.003 \mathrm{CAR}$

From the equation above, it is known that BPRS with the lowest FSR is BPRS Saka Dana Mulia, 2.36\% means that if the assumed value of the independent variable affecting FSR is zero, FSR of BPRS Saka Dana Mulia is $2.36 \%$. On the other hand, BPRS with the highest FSR is BPRS Gunung Slamet, 3.32\% which means that if the assumed value of the independent variable affecting FSR is zero, FSR of BPRS Gunung Slamet is $3.32 \%$.

Table 4 shows that BPRS Saka Dana Mulia has FSR value of 2.36, the lowest among other BPRS, it is due to several factors include the NPR of BPRS Saka Dana Mulia from 2013-2017 experienced an increase from $1.7 \%$ to $9.28 \%$, in this case if NPF continues to increase, it will cause the risk of bad financing which will disrupt the financial sustainability of BPRS. Based on the Financial Services Authority Regulation No. 15 / POJK 03/2017 the net problem financing ratio (NPF Net) should not be more than 5\% (five percent) of total financing. Based on the results of Fauzi and Mahmud (2018), BPRS Saka Dana Mulia shows efficiency in 2013, 2014 and 2015, which is on contrary with the results of this study showing that FSR of BPRS Saka Dana Mulia is the smallest one, among other BPRS.

Based on the results of FSR formulation above, it shows that BPRS Gunung Slamet has the highest FSR due to the fluctuation of NPF of BPRS Gunung Slamet, from $0.51 \%$ to $2.21 \%$. Despite experiencing fluctuations, it still does not exceed POJK provisions of $5 \%$ so that it can be interpreted that the banking will not experience bad financing and its financial sustainability is still safe. The result of this study is in line with the results of Fauzi and Mahmudi (2018) which explains that BPRS Gunung Slamet has shown efficiency from 2012-2016.

Based on the results of panel data regression in Table 3, CAR has a positive effect on Financial Sustanability Ratio of 0.0116 or $1.16 \%$, which means that high CAR ratio affects the ability of the BPRS to measure the capital adequacy to support assets that contain risks. Therefore, the higher the CAR ratio, the better the growth rate of BPRS and can increase the FSR of that BPRS, in which high FSR can be interpreted that BPRS is able to maintain its performance effectively and efficiently. The result of Wahyuni and Fakhruddin (2014) shows that CAR has a positive effect on FSR of Islamic banking in Indonesia.

Based on the results of the above research, OER ratio also affect FSR of BPRS in Central Java for the period of 2013 to 2017 with 0.000 negatively, meaning that higher OER ratios will cause a lower FSR of BPRS and vice versa. High OER can be interpreted that BPRS has not been able to manage company funds efficiently. In the research of Wahyuni and Fakhruddin (2014), OER also has a negative effect on FSR of Islamic banking in Indonesia. Almilia, et al. (2009) reveals that OER also has a negative effect on FSR of domestic private commercial banks in 1995-2005.

\section{Conclusion}

Based on the results of data analysis using fixed effects model, it shows that partially CAR has a positive effect on financial sustainability ratio for $1.16 \%$ or 0.016 while OER variable has a negative effect on financial sustainability ratio for 0.000 . Independent variables (NPF, FDR, ROA, OER and CAR) show a significant influence with a probability value of 0.0000 less than $\alpha 5 \%$, which means that all independent variables (NPF, FDR, ROA, OER and CAR) simultaneously affect Financial Sustanability Ratio. The model performance is also 
pretty good, with $\mathrm{R}^{2}$ of $77.86 \%$. The result of interception of each company shows different results, in which BPRS Saka Dana Mulia has the lowest FSR for $2.36 \%$ which means that if the assumed value of independent variable affecting FSR is zero, then FSR of BPRS Saka Dana Mulia is 2.36\%. While BPRS Gunung Slamet has the highest FSR for $3.32 \%$, which means that if the assumed value of independent variable affecting FSR is zero, then FSR of BPRS Gunung Slamet is $3.32 \%$.

\section{Bibliography}

Almilia, L.S, Shonhadji \& Anggraini, (2009), Faktor-faktor yang Mempengaruhi Financial Sustainability Ratio pada Bank Umum Swasta Nasional Non Devisa Periode 1995-2005. Jurnal Akuntansi dan Keuangan, $11(1), 1-16$

Baltagi, B. H, (2005), Econometric Analysis Of Panel Data, Third Edition, John Wiley \& Sons, Ltd

Fauzi, M, (2018), Efisiensi Bank Pembiayaan Rakyat Syariah (BPRS) di Provinsi Jawa Tengah, Junal Ekonomi \& Keuangan Islam, 4 (1), 31-40

Maryati, S, (2014), Peran Bank Pembiayaan Rakyat Syariah dalam Pengembangan UMKM dan Agribisnis Pedesaan di Sumatera Barat, Journal of Economic and Economic Education (ECONOMICA), 3 (1), 117

Marwati, C. P \& Yulianti, (2015), Analisis Pengungkapan Sustanability Report Pada Perusahaan Non-Keuangan Tahun 2009-2013, Jurnal Dinamika Akuntansi, 7 (2), 167-181

Notoatmojo, Iqbal \& Anita R, (2016), Analisis Faktor-faktor yang mempengaruhi financial sustainability ratio pada bank umum syariah di Indonesia periode 2010-2014, Jurnal Ekonomi Syariah (EQUILIBRIUM), 4 (1), 20-42

Parinduri, R.A, (2016), Family Hardship and The Growth Of Micro And Small Firms In Indonesia. Bulletin of Indonesian Economic Studies.

Rianasari, S \& Pangestuti, (2016), Analisis Rasio Kinerja Keuangan Terhadap Financial Sustanability Bank Perkreditan Rakyat (BPR) di Jawa Tengah periode 2010-2014, Journal of Management, 5 (2), 1-15

Santoso, J. Khairunnisa, \& Triyanto, D.N (2017), Pengaruh Capital Adequacy Ratio, Non Performing Loan, dan Loan To Deposit Ratio terhadap Financial Sustanability Ratio (Studi Kasus Bank Umum Swasta dan Nasional yang Terdaftar di Bursa Efek Indonesia Pada Tahun 2011-2015), Competitive Jurnal Akuntansi dan Keuangan, 1 (2), 67-83

Sriyana, J, (2014), Metode Regresi Data Panel (Dilengkapi Analisis Kinerja Bank Syariah di Indonesia, Yogyakarta: Ekonisia

Sundari, S. Daryanto, A. Tambunan, M \& Saefudin, A (2012), Faktor-faktor yang Mempengaruhi Sustanabilitas Pertumbuhan Financial Lembaga Keuangan Mikro di Jawa Timur, Jurnal Manajemen dan Agribisnis, 9 (1), 31-43

Wahyuni, S \& Fakhruddin, (2014), Analisis Faktor-Faktor yang Mempengaruhi Sustanability Ratio Perbankan Syariah di Indonesia, Proseding Seminar Nasional dan Call For Papper, FEB UMS, 25 Juni 2014.

Widarjono, A, (2017), Ekonometrika (Pengantar dan Aplikasinya Disertai Panduan Eviews), Yogyakarta; UPP STIM YKPN

www. ojk.go.id/ diakses pada bulan januari 2018

www. bi.go.id/ diakses pada bulan januari 2018 